\title{
Tolerance of Informality and Occupational Choices in a Large Informal Sector Economy
}

\author{
Marcelo Arbex (University of Windsor) \\ Marcio V. Correa (Federal University of Ceara) \\ Marcos R. V. Magalhaes (Federal University of Ceara)
}

Working paper 20 - 04

Working papers are in draft form. This working paper is distributed for purposes of comment and discussion only. It may not be reproduced without permission of the copyright holder. Copies of working papers are available from the author or at http://ideas.repec.org/s/wis/wpaper.html. 


\title{
Tolerance of Informality and Occupational Choices in a Large Informal Sector Economy
}

\author{
Marcelo Arbex* Márcio V. Corrêa ${ }^{\ddagger}$ Marcos R.V. Magalhães ${ }^{\dagger}$
}

July 23, 2020

\begin{abstract}
We study an equilibrium occupational choice model where heterogeneous agents decide to become either workers or entrepreneurs in the formal or informal sector. Informal output is subjected to taxation determined by a combination of managers capital choice and the society's tolerance of informality. The model is consistent with empirical evidence for the Brazilian informal sector. The counterfactual analysis shows substantial heterogeneity of policy effects on occupational choices (entrepreneur-worker) and within the entrepreneurial choices (formal-informal). Changes in the society's tolerance of informality lead agents to shift between the two entrepreneurial choices rather than in the entrepreneur-worker dimension.
\end{abstract}

KEYwords: Informal Sector; Social Norms; Credit Constraints; Limited Enforcement. JEL Classification: E6; E26; O11; O17; H26; Z13.

*Department of Economics, University of Windsor, Canada. E-mail: arbex@uwindsor.ca. †CAEN - Graduate Studies in Economics, Federal University of Ceará, Brazil. Email: marciovcorrea@caen.ufc.br; †CAEN Graduate Studies in Economics, Federal University of Ceará, Brazil. Email: marcosrenan@caen.ufc.br . 


\section{Introduction}

In this paper, we study an equilibrium occupational choice model in which agents can choose to became either a manager or a worker in two distinct sectors, formal and informal. Agents are heterogeneous in their initial wealth and their ability to manage a firm. Formal and informal firms transform inputs of physical capital and labor into a single good using capital- and laborintensive technologies, respectively. Only formal sector firms have access to the credit market an exogenous large number of financial intermediaries. Workers are paid the same competitive wage rate in both sectors. The government taxes workers and formal firms and, due to its limited and costly monitoring capacity, a fraction of informal activities goes untaxed. Government tax revenues finance transfers to agents and monitoring costs.

The main novelty of this paper is to study how an endogenous taxation of informal output affects the production distribution in the economy (formal vs. informal) and the occupational choices of agents (entrepreneurs vs. workers). In our framework, a manager operating in the informal sector is subjected to a tax rate, which is determined by a combination of the informal manager's own choice of capital input and the society's tolerance of informality. There are two reasons. First, informal firms tend to operate with lower levels of capital to reduce their visibility and, thus, being detected by the tax authority. The more capital is used in production, more visible informal managers are and the higher is the taxation of their output. Second, we acknowledge the fact that social norms may impose restrictions on the government's punishment of informal activities. For instance, the more tolerant of informality a society is, either in the form of production or consumption of goods produced in the informal sector, the lower the taxation (or punishment) of informal activities. Our goal in this paper is to capture the joint effect of how society sees and tolerates informal production (social norms) and how informal entrepreneurs themselves perceive the punishment imposed by the government, reflected on their (endogenous) choice of capital input. The former is captured by an exogenous parameter calibrated for a large informal sector economy (Brazil), while the latter is expressed in the informal manager's optimal decision taking the society's tolerance of informality as given. The combination of these two features affect the informal entrepreneur's maximization problem and, hence, the general equilibrium effects of policy changes.

Our model is consistent with many empirical findings about the informal sector in Brazil, a developing economy with a large informal sector. Estimates of the share of the informal sector in the official GDP ranges between 32.6\% - 41.7\%, in the period 1991-2015 (Medina and Schneider, 2018). Data from the Brazilian Informal Urban Economy Survey (ECINF) suggest that the informal sector is largely represented by very small firms with at most five employees. Morever, using microdata from the 2008 Brazilian households survey (PNAD), we find that the percent of people in the labor force who employ at least one worker is about $2 \%$ and self-employment accounts for $10 \%$ of the labor force. According to the Brazilian Monthly Employment Survey (PME), the informal sector 
share in the total employment ranged between $22.9 \%-32 \%$, in the period 2002-2012. Defining an entrepreneur as those individuals who manage a labor force with income higher than the minimum wage ( $\mathrm{R} \$ 415$ in 2008), the percent of entrepreneurs in the labor force is about 7.54\%. The ECINF also reports that formal firms employ $84 \%$ more workers that informal ones, in addition to be more productive (Ulyssea, 2018). The calibrated version of our baseline model matches the Brazilian economy fairly well along these abovementioned dimensions and key others.

With a calibrated version of our model, we explore the quantitative implications of policy changes for agents' occupational choice, input allocations and production in the formal and informal sectors. We show that as the society's tolerance of informality decreases, the informal sector employs less labor input and produce less output - informality decreases. Because the taxation of informal activities is endogenously determined by how much capital informal managers use, a less tolerant society imposes a higher taxation per unit of (informal) capital used. Interestingly, the production increase in the formal sector occurs through the extensive margin channel only - workers change occupations towards the formal sector as the society becomes less tolerant of informality. On the other hand, the decrease in the informal sector production is due to less workers working less hours (both extensive and intensive margins). Regarding the occupational choices distribution, we observe that changes in the tolerance of informality parameter lead agents to shift between the two entrepreneurial choices rather than in the entrepreneur-worker dimension.

Changes in labor income and formal output taxation have interesting effects on agents' occupational choices. While a reduction in the labor income tax leads informal entrepreneurs to change their occupation to either become formal sector managers or workers - a lower tax reduces the (gross) equilibrium wage but it increases the (net) take-home wage income - such change in the taxation of formal output increases the profitability of the formal sector, having the effect of not only attracting informal entrepreneurs to switch and become formal managers (of a less laborintensive production technology) but also leading those already operating in the formal sector to expand their production by hiring more workers and employing more capital.

In the model, formal managers can finance capital used in production with their own funds as well as with funds borrowed from an financial intermediary. Managers in the informal sector do not have access to financial intermediaries. More accessibility to financial markets has two main effects. First, informal sector production falls, which is more than compensated by the increase in the output production in the formal sector (larger scale, more efficient sector). Second, we observe only very small changes in the share of formal and informal managers in the economy and, consequently, in the share of workers.

Finally, we investigate, by means of counterfactuals, the impact of different combinations of society's tolerance of informality, formal output taxation and degree financial development on the informal sector production and employment, as well as on the agents' occupational choices. The most interesting result that emerges from this exercise it that in a society that is less tolerant of informal activities the combination of more access to financial markets by formal managers and 
lower taxation of output and labor drives informality to substantially low levels (compatible to developed economies) and increases overall production, consumption and tax revenue.

There is an extensive literature in economics that studies both theoretically and empirically the causes (e.g., low level of human capital, poverty, institutions, social norms, taxation, government regulations, lack of access to finance) and consequences (e.g. poor provision of public goods, income inequality, low tax revenue) of informality, particularly in poor and developing countries. A nonexhaustive list of papers that focus on informality and topics of interest is: contract enforcement (Quintin, 2008), productivity (D'Erasmo and Boedo, 2012), economic development (La Porta and Shleifer, 2014), unemployment benefits (Bosch and Esteban-Pretel, 2015), search frictions in the labor market (Ciccarone et al., 2016), growth (Maiti and Bhattacharyya, 2020), and tax collection Di Caro and Sacchi (2020). See also Schneider and Enste (2000) for a review of the economic literature on informal activities.

This paper is more directly connected to four main strands of the literature. First, studies on individuals' occupational choice decision to become either an informal entrepreneur or an informal worker. In this literature, our article is closely related to Antunes and Cavalcanti (2007) and Amaral and Quintin (2006). Antunes and Cavalcanti (2007) solve numerically a general equilibrium model with credit constrained heterogeneous agents, occupational choices over formal and informal businesses, financial frictions and a government sector which imposes taxes and regulations on formal firms. They find that contract enforcement and regulation costs are equally important in accounting for the size of the informal sector in a developing country. Amaral and Quintin (2006) model the costs associated with producing in the informal sector as resulting from financial frictions. Managers choose to enter the formal sector when the return to outside financing exceeds the additional tax cost they must bear. As a result, the most productive managers self-select into the formal sector, and operate with more capital. We contribute to this literature by considering an endogenous taxation of informal entrepreneurs, based on their capital input decision and the society's tolerance of informality.

Studies have shown that taxation, broadly speaking, is one of the main drivers of informality (e.g., Cerda and Saravia, 2013; López, 2017). On one hand, higher (lower) taxes can discourage formal activities and push agents - workers and entrepreneurs - towards (away from) the informal sector. For instance, Saracoğlu (2008) shows that by reducing formal labor income taxation a country can successfully reduce employment in the informal sector - a result also observed in our analysis. On the other hand, auditing procedures, penalty and fines applied to those caught operating in the informal sector can potentially deter tax evasion and underground activities. Tied to this discussion is the notion of tax morale - the intrinsic or moral obligation to pay taxes, which points to the link between the quality of public policies and social values as potentially a key mechanism behind the low tax compliance rate and high informality observed in many economies (see, for instance, Kolm and Larsen, 2002; Boeri and Garibaldi, 2005; Torgler and Schneider, 2009; Traxler, 2010; Varvarigos, 2017). 
In fact, an individual's tax behavior can be seen as the outcome of the interaction of external factors, e.g., the tax system as an imposed system (see, for instance, Slemrod, 1992; Andreoni et al., 1998) and subjective factors such as taxpayers interdependence with others (e.g., Groenland and van Veldhoven, 1983). Moreover, individuals are rarely in isolation as all are members of social groups, societies and cultures. Consequently, tax behavior is not a function purely of individual's choice: individuals might look to others in order to decide what is acceptable, reasonable, and expected within the social context in which the action is made (Pickhardt and Prinz, 2014). In particular, there is growing evidence that, among other factors, individuals are influenced by the social context in which decisions are made. As Alm (2019) points out, much individual behavior can be broadly viewed as a "psychological contract" between individuals (and also between individuals and government). Central to this contract is the broad notion of a social norm - a pattern of behavior that is judged in a similar way by others and that is sustained in part by social approval or disapproval (Acemoglu and Jackson, 2017). While informality might be tolerated and, to some degree, accepted in some societies, in others, informal activities are perceived as immoral, even illegal. ${ }^{1}$

Third, several papers study the relationship between informality and financial development (e.g., Antunes and Cavalcanti, 2007). Antunes et al. (2008b) shows that differences across countries in intermediation costs and enforcement generate differences in occupational choice, firm size, credit, output and income inequality. Blackburn et al. (2012) study the relationship between the informal sector and financial development in a model of tax evasion and bank intermediation. The key implication of their analysis is that the marginal net benefit of income disclosure increases with the level of financial development. Guo and Hung (2020) find a positive correlation between financial development and the ratio of tax revenue over GDP; a result similar to ours.

Finally, there are several papers that study the Brazilian economy and features of its informal sector. In Ulyssea (2018) informal firms coexist with formal firms which may hire informal workers. Through counterfactual exercises, the author shows that there is substantial heterogeneity in policy effects between groups (switchers, always formal, and always informal firms) and within groups. De Paula and Scheinkman (2011) test implications of a simple equilibrium model of informality using data from the ECINF and verify that formal activities are positively correlated with firms' size and informal firms employ a lower capital-labor ratio. Using a nationally representative Brazilian panel data that covers both formal and informal workers, Gomes et al. (2020) study labor earnings dynamics and document that informality in Brazil is associated with more volatile earnings, while formal sector workers are subject to significant downside risk. See, also, Monteiro and Assuncao (2012) and de Paula and Scheinkman (2010).

Besides this introduction, this paper is organized in three additional sections. Section 2 presents the model. In Section 3 we present the results for a calibrated version of the model, discuss the economic implications of different policy changes and conduct counterfactual analyses. Section 4

\footnotetext{
${ }^{1}$ See Alm et al. (1992), Alm and Torgler (2011), Christian and Alm (2014), Alm et al. (2017), Alm (2019).
} 
concludes.

\section{The Economy}

Time is discrete and the economy goes on forever. Every period, a cohort of measure 1 of oneperiod-lived agents is born. Agents are endowed with one unit of time. Agents are heterogeneous in their initial wealth, as well as their ability to manage a firm. Ability is public knowledge. While initial wealth is inherited from the previous generation, an agent's ability is not.

Agents can choose to become either managers or workers. If an agent decides to become an entrepreneur she can manage either a formal or an informal production technology to produce a single final good. Formal and informal firms produce the same good with different technologies, are subject to different taxation and credit constraints. The decision to become entrepreneur and the size of firms depend on an agent's ability to manage a firm, her initial wealth and her ability to access financial markets. Only formal sector firms have access to the credit market - an exogenous large number of financial intermediaries. These intermediaries rent agents' wealth and lend it at an exogenous and competitive rate. We assume capital fully depreciates. The final good can be either consumed or invested and its price is normalized to one. Instead of managing a firm, agents can work in either formal or informal firms, which pay the same competitive wage rate. A worker does not value leisure and, hence, he inelastically supplies his unity of time to a firm in either sector.

The government taxes workers and formal firms. Due its limited and costly monitoring capacity, the government only detects a fraction of the firms operating in the informal sector. Managers caught operating in the informal sector are subject to tax penalties. The government tax revenue finance transfers to agents and monitoring costs.

\subsection{Preferences and Technologies}

Each agent cares about their current consumption $c_{t}$ and the amount of wealth $b_{t+1}$ they leave for their offspring (Banerjee and Newman, 1993). The utility function is given by:

$$
u\left(c_{t}, b_{t+1}\right)=c_{t}^{\eta} b_{t+1}^{1-\eta}
$$

where $\eta \in(0,1)$ represents the weight of current consumption on the agent's utility function.

An agent with ability $x$, drawn from an ability distribution $F(x)$, that decides to become an entrepreneur, combine labor $(l)$ and capital $(k)$, along with her managerial ability, to produce the same good either in the formal $(i=F)$ or the informal $(i=I)$ sector, according to the following production technology

$$
y_{i}=x A_{i} k_{i}^{\alpha_{i}} l_{i}^{\beta_{i}}
$$

where $\alpha_{i}, \beta_{i} \in(0,1)$ and $k_{i}, l_{i}$ and $A_{i}$ are the capital and labor inputs and the productivity in sector $i=F, I$, respectively. Following Amaral and Quintin (2006), we normalize $A_{F}=1$ and 
assume that productivity is lower in the informal sector $\left(A_{I}<1\right)$. Production technologies exhibit decreasing returns to scale, i.e., $\alpha_{i}+\beta_{i}<1 .^{2}$ We further assume that $\alpha_{I}<\alpha_{F}$, which implies that production in the informal firms is more labor intensive.

\subsection{Workers, Formal and Informal Entrepreneurs}

An agent that decides to become a worker has total wealth $\Pi_{w}(b ; w)$ given by

$$
\Pi_{w}(b ; w)=\left(1-\tau_{w}\right) w+(1+r) b+T
$$

where $\tau_{w}$ is the tax rate on labor income, $w$ is the wage rate in both sectors, $T$ is a lump-sum government transfer irrespective of production sector, $r$ is the rate of return on households' deposits and $b$ is drawn from a wealth distribution $G(b)$. Credit markets are assumed to be imperfect and all borrowing and lending decisions are made by financial intermediaries. They have access to the international capital market, where they can borrow any amount of capital at an exogenous and constant rate, $r$ (Antunes and Cavalcanti, 2007). Domestically, these intermediaries operate in a perfectly competitive market - they receive deposits from households and lend capital to entrepreneurs.

Instead of supplying labor services, agents can choose to become managers. Having made the choice to become entrepreneurs, rather than workers, an agent must decide whether to manage a formal or informal firm. That is, managers can operate in one of two sectors: formal or informal. ${ }^{3}$. The manager's goal is to maximize profit by producing and selling the final good according to the sector-specific production function, equation (2), subject to output taxation, labor and capital costs. That is, for $i=F, I$, the profit maximization problem of a formal and an informal firm, respectively, is as follows:

$$
\Pi_{i}(b, x ; w, r)=\max _{k_{i}, l_{i} \geq 0}\left\{\left(1-\tau_{i}\right) y_{i}-w l_{i}-(1+r)\left(k_{i}-b\right)+T: 0 \leq k_{i} \leq \lambda_{i} b\right\}
$$

Two features of a firm's profit maximization problem deserve particular attention, namely, the credit (collateral) constraint, i.e.,

$$
0 \leq k_{i} \leq \lambda_{i} b
$$

and the output taxation $\tau_{i}$. The amount of capital $k_{i}$ used in production combine the entrepreneur's own capital and capital borrowed from financial intermediaries. A capital-constrained formal manager can obtain additional funds but due to the imperfect enforceability of contracts (Evans and Jovanovic, 1989), the access to additional units of capital is determined by entrepreneurs' wealth through a collateral constraint $0 \leq k \leq \lambda_{F} b$, where $\lambda_{F} \geq 1$. The parameter $\lambda_{F}$ informs the entrepreneur's accessibility to financial markets and the degree of financial development of an

\footnotetext{
${ }^{2}$ Basu and Fernald (1997) find that a typical industry appears to have significantly decreasing returns to scale.

${ }^{3}$ One interpretation for this choice is the decision by managers whether or not to legally declare their establishment (Amaral and Quintin, 2006).
} 
economy (Buera et al., 2015). If $\lambda_{i}=\infty$, the credit market is perfect and there is no barrier to indebtedness. On the other hand, when $\lambda_{i}=1$ the firm capital is financed only by the owner's own resources. This latter is the case of informal firms, which do not have access to credit markets, i.e., $\lambda_{I}=1$. This assumption is in line with most of the literature that studies financial frictions and informal activities that argue that one of the key benefits of formalization is the access to the financial markets.

In line with Hsieh and Klenow (2009) and Restuccia and Rogerson (2008), taxes are modeled as output distorting and $\tau_{i}$ drives the wedge across sectors. The advantage of this approach is that it is possible to change the tax rate and evaluate distortions over firms of different sizes, without affecting their relative demand of capital and labor. Firms operating a formal technology are subject to an exogenously given tax rate $\tau_{F}$ on the their output. Tax collection in the formal sector is straightforward as production can be directly and costlessly observed by the tax authority.

On the other hand, the government can only monitor informal production imperfectly and, hence, a fraction of informal activities goes untaxed. A manager that is operating an informal technology is subject to the following tax rate

$$
\tau_{I}=1-e^{-k_{I} \zeta}
$$

First, notice that this expression reflects the fact that taxation of informal output is endogenous to the amount of capital $k_{I}$ used in production. This means to capture the feature that informal firms operate with lower levels of capital to reduce their visibility and, thus, being detected by the tax authority. The more capital is used in production, the more visible informal managers are and the higher is the taxation of their output.

The parameter $\zeta \geq 0$ is a proxy for the fact that social norms impose restrictions on the government's punishment of informal activities (see Sandmo (2005) and citing literature). Moreover, $\zeta$ captures the combination of a society's intolerance of informality as well as informal manager's perception of how informal activities are tolerated in society and how informal managers are taxed (punished). For instance, it is possible to envision a situation where a society is more lenient towards informal production but the entrepreneur herself is not fully aware of such social norms. On the other hand, social norms might suggest a harsh treatment of informal activities and the entrepreneur is attentive to it.

Restrictions on how informal production are punished can be due to the society's tolerance of informal activities - production and consumption of goods produced in the informal sector. ${ }^{4}$ For instance, in an extreme case of an economy where informal activities are fully accepted (tolerated),

\footnotetext{
${ }^{4}$ Limitations could also be related to the tax code, auditing procedures and monitoring technology. We could alternatively consider that if managers attempt to evade formal taxes by working in the informal sector, they would face a probability of being caught. Given a detection probability, the government punishes informal managers by imposing a penalty proportional to the amount of tax evaded. There is an exogenous maximal penalty level that the government can impose. An upper bound on the penalty is motivated by the fact that countries usually adopt a range for this type of penalty. We abstract from other types of penalties such as imprisonment.
} 
$\zeta=0$ implies that $\tau_{I}=0$ and production in the informal sector is not taxed. The more tolerant a society is, the lower $\zeta$, rendering a lower $\tau_{I}$ and higher net informal profits. On the other hand, a higher value of $\zeta$ characterizes a society that is less tolerant to informality - $\zeta$ can be viewed as the degree of society's intolerance of informality - and, hence, imposes a harsher punishment on informal managers. ${ }^{5}$ Hence, the role of $\tau_{I}$ in our model is to capture the joint effect of how society sees and tolerates informal production (social norms) and how informal entrepreneurs themselves perceive the punishment impose by the government, reflected on their (endogenous) choice of capital input. The combination of these two features affect the informal entrepreneur's maximization problem and, hence, the general equilibrium effects of policy changes.

Formal entrepreneur's profit maximization, equation (4), subject to equation (5), yields the following optimal capital demand functions:

$$
k_{F}= \begin{cases}{\left[x\left(1-\tau_{F}\right)\left(\frac{\alpha_{F}}{1+r}\right)^{1-\beta_{F}}\left(\frac{\beta_{F}}{w}\right)^{\beta_{F}}\right]^{\frac{1}{1-\alpha_{F}-\beta_{F}}},} & \text { if } k_{f}<\lambda_{F} b \\ \lambda_{F} b, & \text { otherwise }\end{cases}
$$

and optimal labor demand functions:

$$
l_{F}= \begin{cases}{\left[x\left(1-\tau_{F}\right)\left(\frac{\alpha_{F}}{1+r}\right)^{\alpha_{F}}\left(\frac{\beta_{F}}{w}\right)^{1-\alpha_{F}}\right]^{\frac{1}{1-\alpha_{F}-\beta_{F}}},} & \text { if } k_{f}<\lambda_{F} b \\ {\left[x\left(1-\tau_{F}\right)\left(\lambda_{F} b\right)^{\alpha_{F}}\left(\frac{\beta_{F}}{w}\right)\right]^{\frac{1}{1-\beta_{F}}},} & \text { otherwise. }\end{cases}
$$

Equations (7) and (9) represent the optimal capital and labor demand decisions of a selffinanced managers operating in the formal sector, respectively. For formal managers that have access to the credit markets, the optimal capital and labor demand functions are given by equations (8) and (10), respectively. ${ }^{6}$. Notice that taxation of formal output $\left(\tau_{F}\right)$ and formal entrepreneur's accessibility to financial markets, measured by the collateral constraint parameter $\left.\left(\lambda_{F} \geq 1\right)\right)$ affect capital and labor allocations, and, thus, the optimal formal firms' profit.

Informal managers maximize profits, equation (4), subject to $\left(\lambda_{I}=1\right)$, equation (5), and $\left(\tau_{I}\right)$, equation (6), which implies the following optimal demand functions for informal capital and labor,

\footnotetext{
${ }^{5}$ We can also interpret the "punishment" of informal activities not just necessarily tied to taxation of informal output. There is large evidence that informal activities are associated or subject to corruption, weak rule of law and business institutions in general. By operating low scale firms, informal managers might avoid engaging in side deals with tax inspectors and cumbersome bureaucracy, but even so be subject to overall costs - e.g., transportation - that lead to production losses.

${ }^{6}$ It is straightforward to show that entrepreneurs that obtain additional funds from financial intermediaries invest all their capital endowments in their firms, see Antunes et al. (2008a).
} 
respectively:

$$
\begin{aligned}
& k_{I}= \begin{cases}{\left[x A_{I}\left(\frac{\left(1-\tau_{I}\right) \alpha_{I}}{1+r}\right)^{1-\beta_{I}}\left(\frac{\left(1-\tau_{I}\right) \beta_{I}-\tau_{I} \epsilon}{w}\right)^{\beta_{I}}\right]^{\frac{1}{1-\alpha_{I}-\beta_{I}}},} & \text { if } k_{I}<b, \\
b, & \text { otherwise },\end{cases} \\
& l_{I}= \begin{cases}{\left[x A_{I}\left(\frac{\left(1-\tau_{I}\right) \alpha_{I}}{1+r}\right)^{\alpha_{I}}\left(\frac{\left(1-\tau_{I}\right) \beta_{I}-\tau_{I} \epsilon}{w}\right)^{1-\alpha_{I}}\right]^{\frac{1}{1-\alpha_{I}-\beta_{I}}},} & \text { if } k_{i}>b, \\
{\left[x A_{I}\left(\frac{b^{\alpha_{I}}\left(\left(1-\tau_{I}\right) \beta_{I}-\tau_{I} \epsilon\right)}{w}\right)\right]^{\frac{1}{1-\beta_{I}}},} & \text { otherwise. }\end{cases}
\end{aligned}
$$

where $\epsilon=\left(\partial \tau_{I} / \partial k_{I}\right)\left(k_{I} / \tau_{I}\right)$ is the elasticity of the informal taxation, i.e., punishment, with respect to the size of the informal capital stock used in production. According to equations (11) - (14), the higher the punishment of informal production, the less labor is used in the informal sector, which leads to a lower demand of capital by non-binding informal entrepreneurs.

The agent's occupational choice - worker vs. entrepreneur, formal vs. informal manager - is the solution of the following maximization problem - i.e., the occupation that generates the highest return among the four possible occupations:

$$
\Pi(\cdot)=\max \left\{\Pi_{w}(b ; w), \Pi_{i}(b, x ; w, r)\right\}, \quad \text { for } i=\{F, I\}
$$

where $\Pi_{w}(b ; w)$ and $\Pi_{i}(b, x ; w, r)$ are given by equations (3) and (4), respectively.

For a given wage rate $w$ and interest rate $r$, the solution of the agent's problem, equation (15) allow us to characterize the mass of entrepreneurs $\mathbb{E}(w, r)$ and workers $\mathbb{W}(w, r)$ in the economy, respectively,

$$
\begin{aligned}
\mathbb{E}(w, r) & =\left\{(b, x) \in \mathcal{O}: \max \left\{\Pi_{F}(b, x ; w, r), \Pi_{I}(b, x ; w, r)\right\} \geqslant \Pi_{w}(b ; w)\right\} \\
\mathbb{W}(w, r) & =\left\{(b, x) \in \mathcal{O}: \Pi_{w}(b ; w)>\max \left\{\Pi_{F}(b, x ; w, r), \Pi_{I}(b, x ; w, r)\right\}\right\}
\end{aligned}
$$

where $\mathcal{O}=[0, \infty) \times[0, \infty)$ and $\mathbb{E}(w, r)+\mathbb{W}(w, r)=1$. And among entrepreneurs, the mass of formal and informal managers are defined as follows, respectively

$$
\begin{aligned}
& \mathbb{E}_{F}(w, r)=\left\{(b, x) \in \mathcal{O}:\left\{\Pi_{F}(b, x ; w, r) \geqslant \Pi_{I}(b, x ; w, r)\right\}\right\} \cap \mathbb{E}(w, r), \\
& \mathbb{E}_{I}(w, r)=\left\{(b, x) \in \mathcal{O}:\left\{\Pi_{I}(b, x ; w, r)>\Pi_{F}(b, x ; w, r)\right\}\right\} \cap \mathbb{E}(w, r),
\end{aligned}
$$

where $\mathbb{E}(w, r)$ is defined in equation (16) and $\mathbb{E}_{F}(w, r) \cup \mathbb{E}_{F}(w, r)=\mathbb{E}(w, r)$. 


\subsection{Government and the Economy's Resource Constraint}

The government finances transfers to entrepreneurs and workers, $\mathbb{T}_{T}=\iint_{(b, x) \in \mathbb{E} \cup \mathbb{W}} T F(x) G(b) d x d b$, and bears an exogenously given (informal sector) monitoring cost $M$, according to the following budget constraint:

$$
\mathbb{T}_{F}+\mathbb{T}_{I}+\mathbb{T}_{w}=\mathbb{T}_{T}+M
$$

where $\mathbb{T}_{i}=\iint_{(b, x) \in \mathbb{E}_{i}} \tau_{i} y_{i} F(x) G(b) d x d b$, for $i=F, I$ represent the amount of taxes collected from formal and informal entrepreneurs and the labor income tax revenue is $\iint_{(b, x) \in \mathbb{W}} \tau_{w} F(x) G(b) d x d b$.

The resource constraint in this economy is

$$
\iint_{(b, x) \in \mathbb{E} \cup \mathbb{W}} \Pi_{i}(b, x) F(x) G(b) d x d b=\iint_{(b, x) \in \mathbb{E} \cup \mathbb{W}}\left(c_{i}+h_{i}\right) F(x) G(b) d x d b
$$

where, abusing notation, $h \equiv b_{t+1}$.

\subsection{Equilibrium}

For a given period $t$, consider an ability distribution $F(x)$, an initial wealth distribution $G(b)$ and the following exogenous parameters: $r$ (economy's interest rate); $\lambda$ (credit market accessibility); $\tau_{i}, i=F, I, \tau_{w}$ (tax rates on formal, informal output and labor) and $\zeta$ (society's tolerance of informal production). Three market clearing conditions - equilibrium in the labor market, in the credit market and in the goods market - are required to determine the wage in each period $t$.

A competitive equilibrium is characterized by the time- $t$ optimal choices $\left\{c^{*}, b^{*}, k_{F}^{*}, k_{I}^{*}, l_{F}^{*}, l_{I}^{*}\right\}$, so that the following conditions are satisfied:

1. The wage rate satisfies:

$$
\iint_{(x, b) \in \mathbb{W}} F(x) G(b) d x d b=\iint_{(x, b) \in \mathbb{E}}\left(l_{F}^{*}+l_{I}^{*}\right) F(x) G(b) d x d b .
$$

2. The capital market clears:

$$
\iint_{(x, b) \in \mathbb{E}}\left(k_{F}^{*}+k_{I}^{*}\right) F(x) G(b) d x d b=\int_{b^{*} \in G(b)} b G(b) d b .
$$

3. The goods market clears:

$$
\iint_{(x, b) \in \mathbb{E}}\left(y_{F}^{*}+y_{I}^{*}\right) F(x) G(b) d x d b=\iint_{(x, b) \in \mathbb{E} \cup \mathbb{W}} c^{*} F(x) G(b) d x d b .
$$


4. The government budget constraint, equation (20) is satisfied.

5. The law of motion of the bequest distribution over time $\left(G_{t+1}\right)$ is given by

$$
G_{t+1}=\int P_{t}\left(b_{t}, A\right) G\left(b_{t}\right) d b_{t} .
$$

where $P_{t}\left(b_{t}, A\right)=\operatorname{Pr}\left\{b_{t+1} \in A \mid b_{t}\right\}$.

The function $P_{t}$ assigns a probability to event $A$ for the descendant of an agent with bequest $b_{t}$ who does not yet know her entrepreneurial talent, $x_{t+1}$. The event $A$ can be seen as the occupational choice endogenously chosen by the agent of the previous generation which leaves different levels of income as bequest for the inheritor. Hence, function $P_{t}$ affects the law of motion of the bequest distribution.

Following Antunes and Cavalcanti (2007) we can characterize a steady-state competitive equilibrium in which the distribution of wealth over the population is constant over time. The steadystate equilibrium is unique and the economy converges to this equilibrium from any initial condition. See Antunes et al. (2008a) for details on the characterization of equilibrium.

\section{Economic Implications of the Model}

In this section we describe the quantitative results for a calibrated version of our model. We calibrate our model to approximate important features of the Brazilian informal sector and economy. With our calibrated model, we explore the quantitative implications of changes in the society's tolerance of informality, taxation and borrowing constraints on occupational choices and aggregate efficiency. We also conduct counterfactual analyses of different policy combinations.

\subsection{Calibration and Parameterization}

The structural parameters of the model are calibrated to match several steady-state observations consistent with other empirical studies in the literature, in particular, specific studies for the Brazilian economy. The parameters to be calibrated include the capital shares, $\alpha_{F}$ and $\alpha_{I}$, and the labor shares in formal and informal production, $\beta_{F}$ and $\beta_{I}$, the productivity of the informal sector, $A_{I}$, the financial friction parameter, $\lambda_{F}$, the economy interest rate, $r$, the tax rate on formal output, $\tau_{F}$, and the tax rate on labor income, $\tau_{w}$. A subset of parameters are jointly calibrated to match specific statistic of the informal sector in Brazil. The calibrated values of the model parameters are summarized in Table I.

The parameters related to the capital and labor shares in the formal and informal sectors are set, in line with Gollin (2002), such that ten percent of total income from production represent the entrepreneur's profit and the chosen values do not imply significant variations in the year to year dynamics of the model. The capital share in the formal sector is set to $\alpha_{F}=0.33$. Following Amaral and Quintin (2006) and consistent with our assumption that $\alpha_{F}>\alpha_{I}$, we set 
Table I: Benchmark parameter calibration.

\begin{tabular}{clcc}
\hline Parameter & Description & Source & Value \\
\hline \multirow{2}{*}{ Preferences } & & \\
\hline$\eta$ & Utility function curvature & $(8)$ & 0.800 \\
& & & \\
Technology & & $(1)$ & 0.330 \\
\hline$\alpha_{F}$ & Formal sector - Capital share & $(1)$ & 0.570 \\
$\beta_{F}$ & Formal sector - Labor share & $(2)$ & 0.300 \\
$\alpha_{I}$ & Informal sector - Capital share & $(1)$ & 0.600 \\
$\beta_{I}$ & Informal sector - Labor share & $(8)$ & 1.000 \\
$A_{F}$ & Formal sector - Productivity & $(3)$ & 0.800 \\
$A_{I}$ & Informal sector - Productivity & &
\end{tabular}

Financial Market

\begin{tabular}{clcc}
\hline$r$ & Interest rate & $(5)$ & 1.814 \\
$\lambda_{F}$ & Financial markets accessibility & $(4)$ & 2.130 \\
& & \\
Tax Policies & & & \\
\hline$\tau_{F}$ & Tax rate on output & $(6)$ & 0.317 \\
$\tau_{w}$ & Tax rate on labor income & $(7)$ & 0.176 \\
& & \\
\multicolumn{2}{l}{ Wealth and Talent Distributions } \\
\hline$\xi$ & Initial wealth (upper bound) & $(8)$ & 1.000 \\
$\chi$ & Talent (upper bound) & $(8)$ & 2.450 \\
\hline
\end{tabular}

Note: Parameter values sources: 1. Gollin (2002); 2. Amaral and Quintin (2006);

3. Ulyssea (2018); 4. Crisóstomo et al. (2014); 5. Allub and Erosa (2019); 6.

Prado (2011); 7. Pereira and Ellery Júnior (2011); 8. Calibrated by authors.

$\alpha_{I}=0.30$. Given that production in both sectors is assumed to exhibit decreasing returns to scale, i.e., $\alpha_{i}+\beta_{i}<1$, we set $\beta_{F}=0.57$ and $\beta_{I}=0.60$ as the labor share in the formal and informal sectors, respectively. The inefficiency of production in informal sector is well established in the literature (see, for instance, La Porta and Shleifer, 2014). More specifically for Brazil, Ulyssea (2018) showed that informal sector productivity is approximately $20 \%$ lower than formal sector productivity. Hence, we set $A_{I}=0.8$ in our benchmark calibration.

The model's real interest rate is set to 1.814, so that the model economy is consistent with its empirical counterpart for a period of 35 years and it implies a steady-state (average annual) real interest rate of 3 percent per year (Allub and Erosa, 2019). The parameter related to the entrepreneur's accessibility to financial markets, $\lambda_{F}$ is calibrated based on few existing studies for Brazil. Crisóstomo et al. (2014) study a panel of non-financial firms in Brazil during the period 1995-2006 and find that the mean leverage ratio is about 113 percent, which would imply, in our model, $\lambda_{F}=2.13$. Notice that this value is close to the one estimated by Paulson et al. (2006) for 
the Thailand's credit market, $\lambda_{F}=2$. It is not straightforward to assign values for the tax rate on formal output $\left(\tau_{F}\right)$ and the tax rate on labor income $\left(\tau_{w}\right)$ due to the complexity of the Brazilian tax code regarding production taxation as well as taxes on formal labor income. We rely on some studies for the Brazilian economy, e.g., Prado (2011) and Pereira and Ellery Júnior (2011), to set benchmark values for these parameters as follows: $\tau_{F}=0.317$ and $\tau_{w}=0.176$.

The rest of the parameters are jointly calibrated so that in the model economy stationary equilibrium, we match four key statistics of the Brazilian economy, namely the share of informal output in the Brazilian Gross Domestic Product (GDP), the share of the informal sector in the total employment measured by the Brazilian Monthly Employment Survey (PME), the fraction of formal entrepreneurs in the population, and the tax burden measured by the Ministry of Economy of Brazil. Particularly, we need values for the curvature of the utility function, $\eta$ and the society's tolerance of informal activities, $\zeta$. We also need values for the distributional parameters $\chi$ and $\xi$, such that an entrepreneur's ability $x$, which is not directly observed, and agents' initial wealth, $b$, are assumed to be uniformly distributed in the population, $x \sim U(0, \chi)$ and $b \sim U(0, \xi)$, respectively (Stiglitz, 1969). The ability distribution $F(x)$ and the wealth distribution $G(b)$ are assumed to be independent of each other. The benchmark values for these parameters are $\eta=0.80$, $\zeta=1.00, \chi=2.45$ and $\xi=1.00$.

Table II reports our key target statistics for the Brazilian economy as well as our model economy. Notice that the model matches the Brazilian economy fairly well along a number of dimensions and we discuss them in more details. Estimates of the share of the informal sector in the official GDP ranges between 41.7\% - 32.6\%, in the period 1991-2015 (Medina and Schneider (2018)). For our numerical exercise, we established the year 2008 for which the informal sector represents $35.1 \%$ of the Brazilian GDP. We set the share of informal sector in total employment measured by the Brazilian Monthly Employment Survey (PME) to 29.4\% (see Barbosa Filho and Moura, 2015). Using microdata from the 2008 Brazilian households survey (PNAD), we find that the percent of people in the labor force who employ at least one worker is about $2 \%$ and self-employment accounts for $10 \%$ of the labor force. However, the data does not allow us to clearly distinguish self-employed who are managing a business or who are employed as a worker, for instance, to avoid Brazil's strict labor laws and regulations. Defining an entrepreneur as those individuals who manage a labor force with income higher than the minimum wage ( $\mathrm{R} \$ 415$ in 2008), the percent of entrepreneurs in the labor force is about 7.54\%, our benchmark value for the fraction of formal entrepreneurs in the population. And our target for the economy's tax burden is around $34.1 \%$ (Ministry of Economy of Brazil).

Interestingly, the model also captures the share of wage workers in the Brazilian economy, which, according to the PME, is around $86 \%$ of the working age population. Given that lack of official data on the number of economic active informal entrepreneurs in Brazil, we calculate this number as the difference between the working age population and the share of formal entrepreneurs and salaried workers in the Brazilian economy. Hence, the share of informal entrepreneurs in our 
Table II: Key statistics: Data and Baseline Economy

\begin{tabular}{lcc}
\hline & Brazilian economy & Baseline model \\
\hline Share of formal entrepreneurs (\%) & 7.5 & 6.2 \\
Share of wage workers (\%) & 85.9 & 85.7 \\
Informal sector in total output (\%) & 35.1 & 35.7 \\
Informal sector in total employment (\%) & 29.4 & 29.0 \\
Standard deviation of informal labor employment & 0.73 & 0.36 \\
Ratio of averages of formal and informal employment & 1.84 & 3.2 \\
Tax collection in total output (\%) & 34.1 & 32.0 \\
\hline
\end{tabular}

Source: Ministry of Economy of Brazil, ECINF, Brazilian households survey (PNAD), Medina and Schneider (2018) and Ulyssea (2018).

benchmark economy is set to $8.1 \%{ }^{7}$

Figure 1 illustrates the distributional features of our (benchmark) calibrated version of the model. Three stylized facts of large informal sector economies are verified here: (i) formal firms are more capital intensive, (ii) informal firms employ a smaller mass of workers as well as less capital, in particular the smaller ones, and (iii) informal firms are concentrated at lower levels of production. Moreover, our calibrated model displays two key statistics of observed in the ECINF data: the standard deviation of informal labor employment and the ratio of formal and informal employment averages. Since the distribution of informal firms with respect to labor input use is mostly concentrated at low levels of this input, a lower standard deviation is expected in this dimension and the model fits well. Also, the model performs well regarding the difference in labor use (vis-à-vis capital) in the formal versus the informal sector - the former employs more labor than the latter. These features of our economy can be visualized in Figure 1.

\subsection{Implications of the Model and Quantitative Exercises}

In this section, we conduct several quantitative exercises to evaluate the impact of changes in key parameters on economic outcomes. Tables III - VI show how the level of production and employment in the informal sector, changes in formal and informal output, tax collection and agent's wage income are affected by a variety of parameter and policy changes. We restrict our attention to those pertinent to the society's tolerance of informality $(\zeta)$, the taxation of labor and formal output, $\tau_{w}$ and $\tau_{F}$, respectively, and the formal entrepreneur's accessibility to financial markets $\left(\lambda_{F}\right)$. To allow comparisons, columns marked with a $*$ in each table shows the results for our benchmark parameterization. We then vary one parameter at a time while all others are kept at their benchmark levels.

Tolerance of Informality. As the society's tolerance of informality decreases, i.e., $\zeta$ increases,

\footnotetext{
${ }^{7}$ Our model does not match the Gini coefficient. It predicts roughly $17 \%$, while the data is $52 \%$, according to the World Development Indicators database. A possible explanation is the fact that in our model, every worker receives the same equilibrium wage rate, while in the data there is much more labor income heterogeneity. We address this in future research.
} 
Figure 1: Distribution of Firms Regarding Labor, Capital and Production
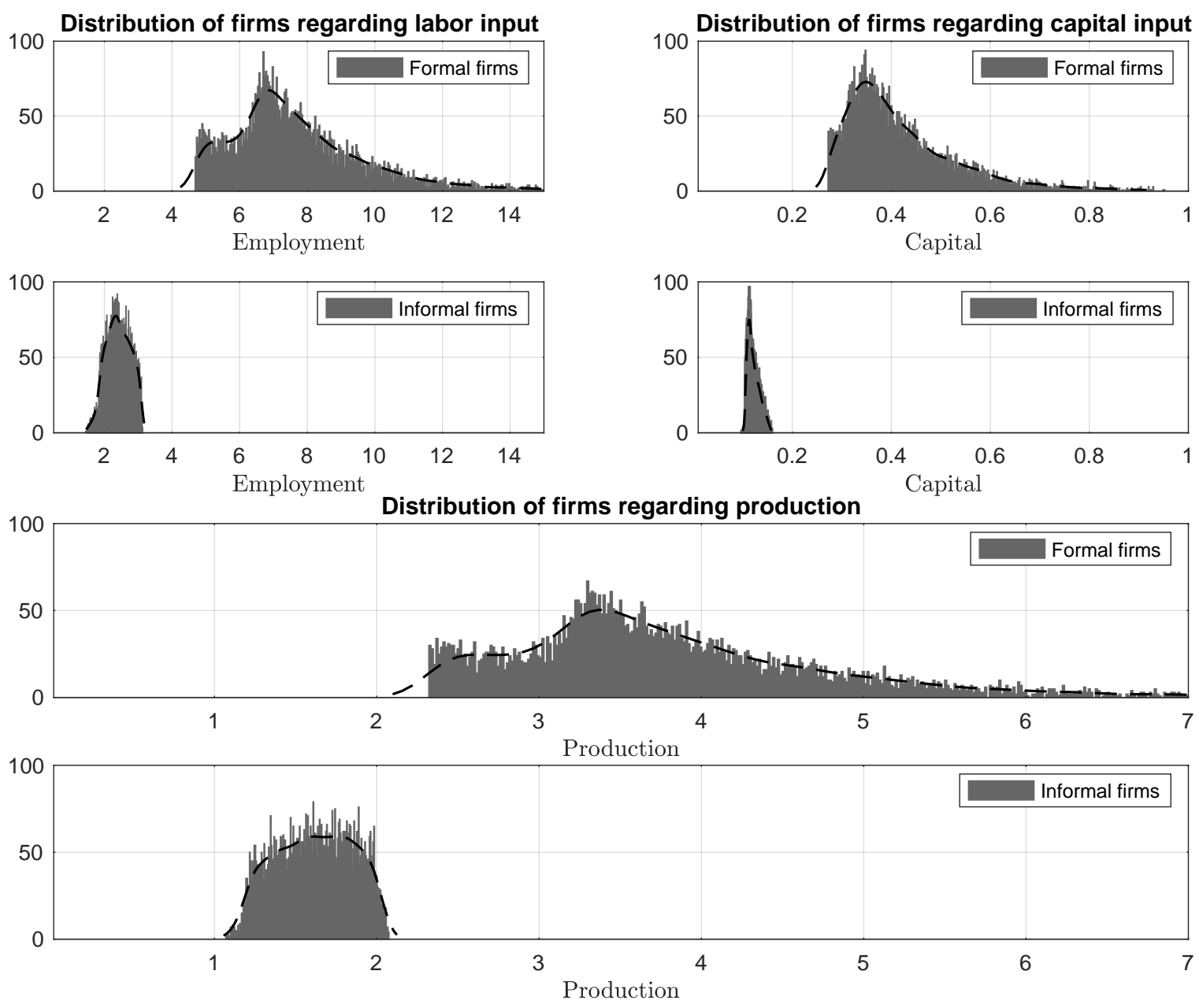

Notes: Our simulations are based on a random draw of 100,000 individuals from the distributions of talent and wealth described previously. Nonparametric kernel-smoothing distribution is used in each frame. The density is evaluated at 100 equally spaced points that cover the range of the data in data.

the informal sector employ less labor input and produce less output - informality decreases (Table III). The case of $\zeta=1.05$ is illustrative - a tolerance level five percent higher than its benchmark. It means that, through its social norms, the society is less tolerant with informality and the government imposes a harsher punishment on informal managers. Notice that, because the taxation of informal activities $\tau_{i}$ is endogenously determined by how much capital is used by informal managers, a bigger $\zeta$ imposes a higher taxation per unit of (informal) capital used. Informal managers react to this change by reducing the capital input more than the use of labor in production - it falls from 27.49 in the baseline to 22.57 and from 29.04 to 23.56, respectively. Moreover, in this case, production in the formal sector increases by about ten percent, while production in the informal sector falls by fifteen percent. Interestingly, the production increase in the former occurs mostly through the extensive margin channel - workers change occupations towards the formal sector as the society becomes less tolerant with informality. On the other hand, the decrease 
Table III: Tolerance of Informality $(\zeta)$

\begin{tabular}{|c|c|c|c|c|c|}
\hline & $\zeta=0.9$ & $\zeta=0.95$ & $\zeta^{*}=1$ & $\zeta=1.05$ & $\zeta=1.1$ \\
\hline \multicolumn{6}{|l|}{ Formal Sector } \\
\hline Production $\left(y_{F}\right)$ & 51.52 & 58.14 & 64.32 & 70.33 & 75.94 \\
\hline Capital $\left(k_{F}\right)$ & 61.36 & 67.26 & 72.51 & 77.43 & 81.87 \\
\hline Labor $\left(l_{F}\right)$ & 58.49 & 65.06 & 70.96 & 76.44 & 81.36 \\
\hline Entrepreneurs ${ }^{1}$ & 4.7 & 5.46 & 6.2 & 6.99 & 7.79 \\
\hline \multicolumn{6}{|l|}{ Informal Sector } \\
\hline$\overline{\text { Production }\left(y_{I}\right)}$ & 48.48 & 41.86 & 35.68 & 26.67 & 24.06 \\
\hline Capital $\left(k_{I}\right)$ & 38.64 & 32.74 & 27.49 & 22.57 & 18.13 \\
\hline Labor $\left(l_{I}\right)$ & 41.51 & 34.94 & 29.04 & 23.56 & 18.64 \\
\hline Entrepreneurs ${ }^{1}$ & 10.21 & 9.17 & 8.1 & 7.02 & 5.91 \\
\hline \multicolumn{6}{|l|}{$\%$ Variation $(\triangle)^{2}$} \\
\hline$\left.\overline{\triangle \text { Output }\left(y_{F}+y_{I}\right.}\right)$ & -2.75 & -1.28 & 0.0 & 1.46 & 2.89 \\
\hline$\triangle y_{F}$ & -22.1 & -10.77 & 0.0 & 10.93 & 21.47 \\
\hline$\triangle y_{I}$ & 32.15 & 15.82 & 0.0 & -15.62 & -30.62 \\
\hline$\triangle$ Consumption & -0.02 & -0.03 & 0.0 & 0.04 & 0.08 \\
\hline$\triangle$ Tax Revenue & -14.06 & 6.87 & 0.0 & 7.00 & 13.76 \\
\hline$\triangle$ Wage income $^{3}$ & 0.83 & 0.36 & 0.0 & -0.28 & -0.51 \\
\hline $\begin{array}{l}\text { Notes: *Baseline value } \\
\text { entrepreneurs in the se }\end{array}$ & $=0.17$ & $\tau_{F}=0.3$ & $=1$, & $=2.13 ;(1)$ & Share of \\
\hline
\end{tabular}

in the informal sector production is due to less workers working less hours (both extensive and intensive margin). The increase in the government's tax revenue is mainly due to the higher production in the formal sector, which more then compensate the drop in the revenue collected from the informal sector. There is an negligible effect in terms of variation in consumption.

Regarding the occupational choices distribution, we observe changes in the tolerance of informality parameter $(\zeta)$ lead agents to shift between the two entrepreneurs choices rather than between the entrepreneur-worker dimension. For instance, for a harsher punishment on informal production, the drop in the share of informal entrepreneurs (from 8.1 in the baseline case to 5.9 in the case of $\zeta=1.10$ ) is pretty much reflected in the increase of share of formal entrepreneurs (from 6.2 to 7.8 , respectively). With this policy change we notice that a very small fraction of agents change their occupation from (informal) entrepreneurs to workers - the share of workers in the population goes from 85.7 in the benchmark to 86.3 when $\zeta=1.10$. The fact that most of the action is across entrepreneurs when $\zeta$ changes can be attributed to the fact that changes on how society tolerate informality either exacerbate (higher $\zeta$ ) or attenuate (lower $\zeta$ ) the (net) output efficiency gap between formal and informal production, i.e., $\left(1-\tau_{i}\right) y_{i}$. 
Table IV: Labor Income Tax $\left(\tau_{w}\right)$

\begin{tabular}{|c|c|c|c|c|c|}
\hline & $\tau_{w}=0.14$ & $\tau_{w}=0.16$ & $\tau_{w}=0.176^{*}$ & $\tau_{w}=0.20$ & $\tau_{w}=0.22$ \\
\hline \multicolumn{6}{|l|}{ Formal Sector } \\
\hline Production $\left(y_{F}\right)$ & 67.56 & 65.73 & 64.32 & 62.22 & 60.26 \\
\hline Capital $\left(k_{F}\right)$ & 75.11 & 73.64 & 72.51 & 70.81 & 69.19 \\
\hline Labor $\left(l_{F}\right)$ & 74.00 & 72.29 & 70.96 & 68.93 & 67.03 \\
\hline Entrepreneurs $^{1}$ & 6.44 & 6.31 & 6.2 & 6.03 & 5.84 \\
\hline \multicolumn{6}{|l|}{ Informal Sector } \\
\hline Production $\left(y_{I}\right)$ & 32.44 & 34.27 & 35.68 & 37.78 & 39.74 \\
\hline Capital $\left(k_{I}\right)$ & 24.89 & 26.36 & 27.49 & 29.19 & 30.81 \\
\hline Labor $\left(l_{I}\right)$ & 26.00 & 27.71 & 29.04 & 31.07 & 32.97 \\
\hline Entrepreneurs ${ }^{1}$ & 7.29 & 7.76 & 8.1 & 8.62 & 9.08 \\
\hline \multicolumn{6}{|l|}{$\%$ Variation $(\triangle)^{2}$} \\
\hline$\left.\overline{\triangle \text { Output }\left(y_{F}+y_{I}\right.}\right)$ & 0.56 & 0.34 & 0.0 & -0.73 & -1.68 \\
\hline$\triangle y_{F}$ & 5.62 & 2.54 & 0.0 & -3.98 & -7.9 \\
\hline$\triangle y_{I}$ & -8.56 & -3.62 & 0.0 & 5.13 & 9.52 \\
\hline$\triangle$ Consumption & 2.96 & 1.32 & 0.0 & -1.99 & -3.64 \\
\hline$\triangle$ Tax Revenue & -3.71 & -1.63 & 0.0 & 2.34 & 3.92 \\
\hline$\triangle$ Wage income ${ }^{3}$ & -0.25 & -0.13 & 0.0 & 0.24 & 0.51 \\
\hline
\end{tabular}

Notes: ${ }^{*}$ Baseline values: $\tau_{w}=0.176, \tau_{F}=0.317, \zeta=1, \lambda_{F}=2.13$; (1) Share of entrepreneurs in the sector. Share of workers is one minus the sum of the shares of entrepreneurs in the formal and informal sectors; (2) \% variation relative to the benchmark case; (3) Gross wage income.

Labor Income Taxation. Compared to the benchmark case, an immediate effect of a lower tax on the agent's labor income $\tau_{w}$ is to increase the worker (net) wage income, making this occupation more attractive in both sectors. A lower $\tau_{w}$ also reduced the equilibrium wage rate $w$ implying that, on one hand, the labor costs for firms is lower but, on the other hand, the wage income for workers is also lower. From the agent's point of view, a reduction of taxes on wage has two important effects: it reduces the (gross) equilibrium wage $(w)$ while it increases the (net) take-home wage income $\left(1-\tau_{w}\right) w$. In equilibrium, the latter effect dominates the former and leads to an increase in the number of agents that choose to become workers rather than entrepreneurs. Following a reduction in the labor taxation $\left(\tau_{w}\right)$ and the associated contraction of the (gross) equilibrium wage $(w)$, we observe an occupational choice rearrangement - informal entrepreneurs change their occupation to either become formal sector managers or workers.

Consider, for instance, the labor income tax fall from the baseline level to $\tau_{w}=0.14$. In this case, the share of formal entrepreneurs in the population is 6.44 (up from 6.2 in the baseline), the informal managers share is 7.29 (down from 8.1) and the share of workers in the economy is 86.27 (up from 85.7). Entrepreneurs move from the informal to the formal sector, a sector that 
is overall more productive and less labor intensive - the marginal benefit of a lower labor income taxation is higher in the formal sector, which leads formal entrepreneurs to hire more workers (see Figure 1) and produce more. In fact, the rise in formal output occurs due to two channels. Formal entrepreneurs can scale their production up as labor is cheaper (intensive margin) and there are now more formal managers, those that switched from the informal sector to the formal sector (extensive margin). The formal product increased by 2.54 and $5.62 \%$, followed by the decrease in informality, for $\tau_{w}$ contractions of $2\left(\tau_{w}=0.16\right)$ and $4\left(\tau_{w}=0.14\right)$ percentage points, respectively. In terms of welfare, as measured by the economy's consumptuon level, there is a significant increase with successive decreases in taxation on labor income. Finally, the level of government revenue is decreasing, despite the increase in the tax base of the tax in question and the increase in the formalization of the economy.

Formal Output Taxation. Table V presents the effects of changes in the taxation of formal output $\tau_{F}$. Decreases in $\tau_{F}$ increase the profitability of the formal sector. Such policy change has the effect of not only attracting informal entrepreneurs to switch and to become formal managers (of a less labor-intensive production technology) but also leading those entrepreneurs already operating in the formal sector to expand their production - hiring more workers and employing more capital. Consider, for instance, the case of $\tau_{F}=0.297$. For a relative small decrease in the taxation of formal output, about two percentage points, we observe a substantial decrease in the share of informal managers, which drops from 8.1 in the baseline $\left(\tau_{F}=0.317\right)$ to $5.48\left(\tau_{F}=0.297\right)$, and an increase in the share of formal managers in the economy (from 6.2 to 8.4, respectively). Successive decreases in the formal output taxation lead to higher levels of consumption and welfare improvements.

Comparing the effect of changes in the two tax instruments, i.e., the labor income tax $\left(\tau_{w}\right)$ and the tax on formal output $\left(\tau_{F}\right)$, on the government tax revenue, we observe that while reductions of $\tau_{w}$ lead to a drop in the government tax revenues (Table IV), lowering $\tau_{F}$ increase tax revenue for the government (Table V). This result might suggest that, regarding the taxation of output produced in the formal sector, the Brazilian economy is on the "wrong side" of the Laffer curve. ${ }^{8}$

Entrepreneur's Accessibility to Financial Markets. Compared to the benchmark case, a higher accessibility to financial markets $\lambda_{F}$ has two effects (Table VI). First, formal sector managers have more access to credit in order to finance production. This leads to a drop in the informal sector production, which is more than compensated by the increase in the output production in the formal sector (larger scale). The overall effect of more access to additional funds leads to more production in the more efficient sector and, consequently, more output and consumption. Second, the (gross) equilibrium wage $(w)$ increases. A higher wage makes being a worker a more attractive

\footnotetext{
${ }^{8}$ The "wrong side" of the Laffer Curve denotes a situation in which the tax rate is greater than the one that would maximize total tax revenue (Trabandt and Uhlig (2011)). A reduction in the current tax rate would, hence, increase the tax revenue.
} 
Table V: Formal Output Tax $\left(\tau_{F}\right)$

\begin{tabular}{|c|c|c|c|c|c|}
\hline & $\tau_{F}=0.297$ & $\tau_{F}=0.307$ & $\tau_{F}=0.317^{*}$ & $\tau_{F}=0.327$ & $\tau_{F}=0.337$ \\
\hline \multicolumn{6}{|l|}{ Formal Sector } \\
\hline Production $\left(y_{F}\right)$ & 78.43 & 69.30 & 64.32 & 58.50 & 53.74 \\
\hline Capital $\left(k_{F}\right)$ & 83.33 & 76.40 & 72.51 & 67.85 & 63.95 \\
\hline Labor $\left(l_{F}\right)$ & 82.97 & 75.27 & 70.96 & 65.78 & 61.42 \\
\hline Entrepreneurs ${ }^{1}$ & 8.40 & 6.89 & 6.2 & 5.49 & 4.99 \\
\hline \multicolumn{6}{|l|}{ Informal Sector } \\
\hline$\overline{\text { Production }\left(y_{I}\right)}$ & 21.57 & 30.70 & 35.68 & 41.50 & 46.26 \\
\hline Capital $\left(k_{I}\right)$ & 16.67 & 23.60 & 27.49 & 32.15 & 36.05 \\
\hline Labor $\left(l_{I}\right)$ & 17.03 & 24.73 & 29.04 & 34.22 & 38.58 \\
\hline Entrepreneurs ${ }^{1}$ & 5.48 & 7.22 & 8.1 & 9.09 & 9.88 \\
\hline \multicolumn{6}{|l|}{$\%$ Variation $(\triangle)^{2}$} \\
\hline$\overline{\triangle \text { Output }\left(y_{F}+y_{I}\right)}$ & 6.45 & 1.82 & 0.0 & -1.86 & -2.97 \\
\hline$\triangle y_{F}$ & 29.81 & 9.69 & 0.0 & -10.74 & -18.94 \\
\hline$\triangle y_{I}$ & -35.65 & -12.38 & 0.0 & 14.15 & 25.82 \\
\hline$\triangle$ Consumption & 1.80 & 0.85 & 0.0 & -1.43 & -3.09 \\
\hline$\triangle$ Tax Revenue & 15.70 & 5.13 & 0.0 & -5.74 & -10.19 \\
\hline$\triangle$ Wage income $^{3}$ & 2.62 & 1.12 & 0.0 & -1.58 & -3.17 \\
\hline
\end{tabular}

Notes: ${ }^{*}$ Baseline values: $\tau_{w}=0.176, \tau_{F}=0.317, \zeta=1, \lambda_{F}=2.13$; (1) Share of entrepreneurs in the sector. Share of workers is one minus the sum of the shares of entrepreneurs in the formal and informal sectors; (2) \% variation relative to the benchmark case; (3) Gross wage income.

occupation compared to being an informal manager. Also, through this channel informality falls, in both output and employment dimensions. Higher wages and higher formal output increase the government tax base and, hence, the government's labor income and output tax revenues (as in Lopez-Martin, 2019).

An interesting result emerges from this numerical exercise regarding the agents' occupational choices. Compared to the benchmark case $\left(\lambda_{F}=2.13\right)$, we observe only very small changes in the share of formal and informal managers in the economy and, consequently, in the share of workers. Consider an economy where access to the financial markets is tighter, for instance, $\lambda_{F}=1.90$. The fact that both shares of formal and informal entrepreneurs increase, albeit by very little, when the financial markets is less accessible can be attributed to a reduction in the equilibrium wage, which make the worker occupation relatively less attractive. While a lower $\lambda_{F}$ makes it harder for formal managers to access additional funds to finance their production, it also, in equilibrium, lowers the returns for those that choose to be workers. Intuitively, lower access to credit in the formal sector reduces the demand for labor and the equilibrium wage level. Hence, the net effect is an (almost negligible) increase in the share of entrepreneurs vis-à-vis the share of workers in the economy. 
Table VI: Entrepreneur's Accessibility to Financial Markets $\left(\lambda_{F}\right)$

\begin{tabular}{|c|c|c|c|c|c|c|}
\hline & $\lambda_{F}=1.9$ & $\lambda_{F}=2.13^{*}$ & $\lambda_{F}=2.3$ & $\lambda_{F}=2.5$ & $\lambda_{F}=2.8$ & $\lambda_{F}=3$ \\
\hline \multicolumn{7}{|l|}{ Formal Sector } \\
\hline Production $\left(y_{F}\right)$ & 62.19 & 64.32 & 65.59 & 67.49 & 69.97 & 72.01 \\
\hline Capital $\left(k_{F}\right)$ & 70.54 & 72.51 & 73.74 & 75.26 & 7.27 & 78.82 \\
\hline Labor $\left(l_{F}\right)$ & 69.07 & 70.96 & 72.16 & 73.75 & 75.92 & 77.70 \\
\hline Entrepreneurs $^{1}$ & 6.24 & 6.2 & 6.15 & 6.2 & 6.26 & 6.41 \\
\hline \multicolumn{7}{|l|}{ Informal Sector } \\
\hline Production $\left(y_{I}\right)$ & 37.81 & 35.68 & 34.31 & 32.51 & 30.03 & 27.99 \\
\hline Capital $\left(k_{I}\right)$ & 29.46 & 27.49 & 26.26 & 24.74 & 22.73 & 21.18 \\
\hline Labor $\left(l_{I}\right)$ & 30.93 & 29.04 & 27.84 & 6.25 & 24.08 & 22.30 \\
\hline Entrepreneurs ${ }^{1}$ & 8.54 & 8.1 & 7.79 & 7.46 & 6.98 & 6.61 \\
\hline \multicolumn{7}{|l|}{ \% Variation $(\triangle)^{2}$} \\
\hline$\overline{\triangle \text { Output }\left(y_{F}+y_{I}\right)}$ & 0.44 & 0.0 & -0.8 & -0.6 & 0.55 & 0.02 \\
\hline$\triangle y_{F}$ & -2.88 & 0.0 & 1.31 & 4.31 & 8.18 & 11.98 \\
\hline$\triangle y_{I}$ & 6.44 & 0.0 & -4.6 & -9.41 & -16.30 & -21.14 \\
\hline$\triangle$ Consumption & -0.7 & 0.0 & 0.4 & 0.77 & 1.22 & 1.41 \\
\hline$\triangle$ Tax Revenue & -2.32 & 0.0 & 1.2 & 3.40 & 6.28 & 8.94 \\
\hline$\triangle$ Wage income ${ }^{3}$ & -0.76 & 0.0 & 0.59 & 1.04 & 1.69 & 2.04 \\
\hline
\end{tabular}

Notes: ${ }^{*}$ Baseline values: $\tau_{w}=0.176, \tau_{F}=0.317, \zeta=1, \lambda_{F}=2.13$; (1) Share of entrepreneurs in the sector. Share of workers is one minus the sum of the shares of entrepreneurs in the formal and informal sectors; (2) \% variation relative to the benchmark case; (3) Gross wage income.

Some Counterfactuals Policy Combinations. As presented in Tables III - VI, changes in $\zeta, \tau_{w}, \tau_{F}$ and $\lambda_{F}$, one at a time, affect the agent's occupational choice as well as the level of production, optimal capital and labor allocations and the government tax revenue. The dynamics of the economy and the importance of policy changes are especially apparent in the occupational choices outcomes of the model. Table VII presents the results of our final exercise, where we investigate, by means of counterfactuals, the impact of different combinations of tolerance of informality, formal output taxation and degree of financial development on the informal sector production and employment, as well as on the agents' occupational choices. Recall that the Brazilian economy is our baseline economy where the tolerance of informality, the labor tax income, the formal output tax and the accessibility of financial markets are as follows: $\zeta=1, \tau_{w}=0.176$, $\tau_{F}=0.317$ and $\lambda_{F}=2.13$, respectively.

Our first experiment is to consider an economy that is less tolerant of informality, taxes labor and output at higher rates and formal managers have more access to the financial markets $\zeta=1.5, \tau_{w}=0.22, \tau_{F}=0.34$ and $\lambda_{F}=2.50$, column (I), Table VII. These values are meant to resemble economies with strong tax enforcement, tax morale environment, along with high levels of taxation. In this case, we observe a drop in the variables representing the informal sector, e.g., 
Table VII: Policy Combination $\left(\zeta, \tau_{w}, \tau_{F}, \lambda_{F}\right)$

\begin{tabular}{|c|c|c|c|c|c|}
\hline & Baseline & (I) & (II) & (III) & (IV) \\
\hline & $\begin{array}{l}\zeta^{*}=1.000 \\
\tau_{w}^{*}=0.176 \\
\tau_{F}^{*}=0.317 \\
\lambda_{F}^{*}=2.130\end{array}$ & $\begin{aligned} \zeta & =1.500 \\
\tau_{w} & =0.220 \\
\tau_{F} & =0.340 \\
\lambda_{F} & =2.500\end{aligned}$ & $\begin{aligned} \zeta^{*} & =1.000 \\
\tau_{w} & =0.160 \\
\tau_{F} & =0.300 \\
\lambda_{F} & =2.500\end{aligned}$ & $\begin{aligned} \zeta & =1.250 \\
\tau_{w} & =0.160 \\
\tau_{F} & =0.340 \\
\lambda_{F} & =2.500\end{aligned}$ & $\begin{aligned} \zeta^{*} & =1.000 \\
\tau_{w} & =0.227 \\
\tau_{F} & =0.289 \\
\lambda_{F} & =7.500\end{aligned}$ \\
\hline \multicolumn{6}{|l|}{ Formal Sector } \\
\hline Production $\left(y_{F}\right)$ & 64.24 & 92.66 & 86.51 & 80.08 & 96.62 \\
\hline Capital $\left(k_{F}\right)$ & 72.51 & 94.58 & 89.37 & 85.53 & 94.43 \\
\hline Labor $\left(l_{F}\right)$ & 70.96 & 94.98 & 89.64 & 85.37 & 94.35 \\
\hline Entrepreneurs $^{1}$ & 6.2 & 10.32 & 9.2 & 7.69 & 9.00 \\
\hline \multicolumn{6}{|l|}{ Informal Sector } \\
\hline Production $\left(y_{I}\right)$ & 35.68 & 7.34 & 13.49 & 19.92 & 7.38 \\
\hline Capital $\left(k_{I}\right)$ & 27.49 & 5.42 & 10.63 & 14.47 & 5.57 \\
\hline Labor $\left(l_{I}\right)$ & 29.04 & 5.02 & 10.36 & 14.63 & 5.65 \\
\hline Entrepreneurs ${ }^{1}$ & 8.1 & 2.27 & 3.73 & 4.91 & 2.47 \\
\hline \multicolumn{6}{|l|}{$\%$ Variation $(\triangle)^{2}$} \\
\hline$\triangle$ Output $\left(y_{F}+y_{I}\right)$ & 0.0 & 6.71 & 11.08 & 0.27 & 22.91 \\
\hline$\triangle y_{F}$ & 0.0 & 53.73 & 49.40 & 24.84 & 76.97 \\
\hline$\triangle y_{I}$ & 0.0 & -78.05 & -57.99 & -44.02 & -74.97 \\
\hline$\triangle$ Consump & 0.0 & -0.32 & 1.05 & 4.35 & 8.82 \\
\hline$\triangle$ Tax Revenue & 0.0 & 49.3 & 24.85 & 17.49 & 55.81 \\
\hline$\triangle$ Wage income $^{3}$ & 0.0 & -4.43 & 3.65 & -4.13 & 9.62 \\
\hline
\end{tabular}

Notes: ${ }^{*}$ Baseline values: $\tau_{w}=0.176, \tau_{F}=0.317, \zeta=1, \lambda_{F}=2.13$; (1) Share of entrepreneurs in the sector. Share of workers is one minus the sum of the shares of entrepreneurs in the formal and informal sectors; (2) \% variation relative to the benchmark case; (3) Gross wage income.

output and share of entrepreneurs. While the share of formal entrepreneurs increase, it less than compensate the fall in the share of informal entrepreneurs, leading to an increase in the share of workers in the economy. This new occupational choice composition - more towards workers, and less managers - can be attributed to higher taxes on output and labor input $\left(\tau_{w}, \tau_{F}\right)$, which reduces firms' profits, in a society that is more intolerant of informal activities (high $\zeta$ ) and despite the fact that managers can access additional funds more easily (higher $\lambda_{F}$ ).

The economy represented by column (II) of Table VII has the tolerance of informality at the baseline value and the access to the financial markets similar to the previous exercise, i.e., $\zeta=1$ and $\lambda_{F}=2.50$, respectively, and reduces the economy's labor $\left(\tau_{w}=0.16,\right)$ and output $\left(\tau_{F}=0.30\right)$ tax rates. The combination of more access to financial markets and lower taxes on output and labor drives informality to $13.5 \%$ of total output, a significant reduction when compared to the baseline case. 
From the economy in column (II) to column (III) in Table VII, we increase the formal output tax rate to $\tau_{F}=0.34$ and the intolerance towards the informal sector by $25 \%$. Compared to an otherwise similar economy (column II), the share of workers falls, formal output decreases and tax revenue decreases slightly. Relative to the baseline case, there are less informal managers and less managers in total, i.e., more workers - the net wage is higher (lower $\tau_{w}$, relative to the baseline), despite a lower (gross) equilibrium wage $(w)$.

Finally, column (IV), Table VII aims to mimic the parameters for the United States (US) economy. According to Buera et al. (2015), the degree of financial development in the US is $\lambda=7.5$. We set the production and payroll tax rate equal to $\tau_{F}=0.289$ (Prado, 2011) and $\tau_{w}=0.227$ (Tax Policy Center), respectively. Under this policy combination, if workers face a higher labor income tax but formal managers have more access to the financial markets and pay lower taxes on the output they produce, formal (informal) production increases (decreases), and the overall occupational distribution - workers, formal and informal entrepreneurs - changes significantly. Welfare improves the most under this policy combination. Interestingly, the model fits to US economy well regarding the size of the informal sector, which according to Medina and Schneider (2018), is about $7.75 \%$ of total output. ${ }^{9}$

\section{Conclusions}

This paper investigates how an endogenous taxation of informal output affects the production distribution in the economy (formal vs. informal) and the occupational choices of agents (entrepreneurs vs. workers). We develop a framework where a manager operating in the informal sector is subjected to a tax rate, determined by a combination of the informal manager's own choice of capital input and the society's tolerance of informality. The latter is the main novelty of the paper. In our theoretical model and quantitative exercises, we capture the joint effect of how society sees and tolerates informal production (social norms) and how informal entrepreneurs themselves perceive the punishment imposed by the government, reflected on their (endogenous) choice of capital input. The combination of these two features affect the informal entrepreneur's maximization problem and, hence, the general equilibrium effects of policy changes.

Our model is consistent with many empirical findings about the informal sector in Brazil, a developing economy with a large informal sector. With a calibrated version of our model, we explore the quantitative implications of policy changes for agents' occupational choice and production and input allocations in the formal and informal sectors. In particular, we show that as the society's tolerance of informality decreases, the informal sector employs less labor input and produce less output - informality decreases. Because the taxation of informal activities is endogenously determined by how much capital informal managers use, a less tolerant society imposes a higher taxation per unit of (informal) capital used. We also observe that changes in

\footnotetext{
${ }^{9}$ Additional exercises are presented in the Appendix.
} 
the society's tolerance of informality lead agents to shift between the two entrepreneurial choices rather than entrepreneur-worker dimension.

The counterfactual exercises show that there is substantial heterogeneity in policy effects between occupational choices (entrepreneur versus worker) and within the entrepreneurial choices (formal versus informal). While a reduction in the labor income tax leads informal entrepreneurs to change their occupation to either become formal sector managers or workers, such change in the taxation leads those already operating in the formal sector to expand their production by hiring more workers and employing more capital. We observe only very small changes in the share of formal and informal managers in the economy and, consequently, in the share of workers due to more accessibility to financial markets. Overall, the results show that informality is substantially lower (while output, consumption and tax revenue are higher) in economies that are less tolerant of informal activities, formal entrepreneurs have more access to financial markets and taxation of output and labor is lower.

\section{References}

Acemoglu, D. And M. O. Jackson (2017): "Social Norms and the Enforcement of Laws," Journal of the European Economic Association, 15, 245-295.

Allub, L. AND A. Erosa (2019): "Financial frictions, occupational choice and economic inequality," Journal of Monetary Economics, 107, 63 - 76.

Alm, J. (2019): "WHAT MOTIVATES TAX COMPLIANCE?" Journal of Economic Surveys, $33,353-388$.

Alm, J., M. Bernasconi, S. Laury, D. J. Lee, And S. Wallace (2017): "Culture, compliance, and confidentiality: Taxpayer behavior in the United States and Italy," Journal of Economic Behavior $\&$ Organization, 140, 176 - 196.

Alm, J., G. H. MCClelland, And W. D. Schulze (1992): "Why do people pay taxes?" Journal of Public Economics, 48, 21-38.

Alm, J. And B. Torgler (2011): "Do Ethics Matter? Tax Compliance and Morality," Journal of Business Ethics, 101, 635-651.

Amaral, P. S. And E. Quintin (2006): "A competitive model of the informal sector," Journal of Monetary Economics, 53, 1541-1553.

Andreoni, J. ET AL. (1998): “Tax compliance," Journal of Economic Literature, 818-860.

Antunes, A. And T. Cavalcanti (2007): "Start Up Costs, Limited Enforcement, and the Hidden Economy," European Economic Review, 51, 203-224. 
Antunes, A., T. Cavalcanti, And A. Villamil (2008a): "Computing general equilibrium models with occupational choice and financial frictions," Journal of Mathematical Economics, $44,553-568$.

(2008b): "The Effect of Financial Repression and Enforcement on Entrepreneurship and Economic Development," Journal of Monetary Economics, 55, 278-298.

Banerjee, A. V. And A. F. Newman (1993): "Occupational Choice and the Process of Development," Journal of Political Economy, 101, 274-298.

Barbosa Filho, F. D. H. And R. L. D. Moura (2015): "Evolução recente da informalidade do emprego no Brasil: uma análise segundo as características da oferta de trabalho e o setor," Pesquisa e planejamento econômico, 45, 101-124.

Basu, S. And J. G. Fernald (1997): "Returns to scale in US production: Estimates and implications," Journal of political economy, 105, 249-283.

Blackburn, K., N. Bose, and S. Capasso (2012): "Tax evasion, the underground economy and financial development," Journal of Economic Behavior \& Organization, 83, 243-253.

Boeri, T. And P. Garibaldi (2005): "Shadow sorting," in NBER International Seminar on Macroeconomics, University of Chicago Press, 125-163.

Bosch, M. And J. Esteban-Pretel (2015): "The labor market effects of introducing unemployment benefits in an economy with high informality," European Economic Review, 75, 1-17.

Buera, F. ET AL. (2015): "Anatomy of a Credit Crunch: From Capital to Labor Markets," Review of Economic Dynamics, 101-117.

Cerda, R. A. And D. Saravia (2013): "Optimal taxation with heterogeneous firms and informal sector," Journal of Macroeconomics, 35, 39-61.

Christian, R. C. And J. Alm (2014): "Empathy, sympathy, and tax compliance," Journal of Economic Psychology, 40, 62 - 82, special Issue on Behavioral Dynamics of Tax Evasion.

Ciccarone, G., F. Giuli, And E. Marchetti (2016): "Search frictions and labor market dynamics in a real business cycle model with undeclared work," Economic Theory, 62, 409-442.

Crisóstomo, V. L., F. J. L. Iturriaga, and E. V. GonzÁlez (2014): "Financial constraints for investment in Brazil," International Journal of Managerial Finance, 10, 73-92.

De Paula, A. And J. A. Scheinkman (2010): "Value-Added Taxes, Chain Effects, and Informality," American Economic Journal: Macroeconomics, 2, 195-221. 
De Paula, A. And J. A. Scheinkman (2011): "The informal sector: An equilibrium model and some empirical evidence from Brazil," Review of Income and Wealth, 57, S8-S26.

D'Erasmo, P. N. And H. J. M. Boedo (2012): "Financial structure, informality and development," Journal of Monetary Economics, 59, 286-302.

Di CARo, P. AND A. SACCHI (2020): "The heterogeneous effects of labor informality on VAT revenues: Evidence on a developed country," Journal of Macroeconomics, 63, 103190.

Evans, D. S. And B. Jovanovic (1989): "An Estimated Model of Entrepreneurial Choice under Liquidity Constraints," Journal of Political Economy, 97, 808-827.

Gollin, D. (2002): “Getting Income Shares Right," Journal of Political Economy, 110, 458-474.

Gomes, D., F. Iachan, And C. Santos (2020): "Labor Earnings Dynamics in a Developing Economy with a Large Informal Sector," Journal of Economic Dynamics and Control, 113.

Groenland, E. A. G. And G. M. van Veldhoven (1983): "Tax evasion behavior: A psychological framework," Journal of Economic Psychology, 3, 129-144.

Guo, J.-T. AND F.-S. Hung (2020): "Tax evasion and financial development under asymmetric information in credit markets," Journal of Development Economics, 102463.

Hsieh, C.-T. And P. J. Klenow (2009): "Misalocation and Manufacturing TFP in China and India," The Quarterly Journal of Economics, 1403-1448.

Kolm, A.-S. And B. LARSEn (2002): "Social norm, the informal sector, and unemployment," FinanzArchiv/Public Finance Analysis, 407-424.

La Porta, R. AND A. Shleifer (2014): "Informality and development," Journal of Economic Perspectives, 28, 109-26.

López, J. J. (2017): "A quantitative theory of tax evasion," Journal of Macroeconomics, 53, $107-126$.

Lopez-Martin, B. (2019): "Informal sector misallocation," Macroeconomic Dynamics, 23, 30653098.

Maiti, D. And C. Bhattacharyya (2020): "Informality, enforcement and growth," Economic Modelling, 84, 259-274.

Medina, L. And F. Schneider (2018): "Shadow Economies Around the World: What Did We Learn Over the Last 20 Years?" IMF Working Paper, 18. 
Monteiro, J. C. And J. J. Assuncho (2012): "Coming out of the shadows? Estimating the impact of bureaucracy simplification and tax cut on formality in Brazilian microenterprises," Journal of Development Economics, 99, 105-115.

Paulson, A. L., R. M. Townsend, And A. Karaivanov (2006): "Distinguishing limited liability from moral hazard in a model of entrepreneurship," Journal of political Economy, 114, 100-144.

Pereira, F. M. And R. Ellery Júnior (2011): "Política fiscal, choques externos e ciclo econômico no Brasil," Economia, 12, 445-474.

Pickhardt, M. And A. Prinz (2014): "Behavioral dynamics of tax evasion - A survey," Journal of Economic Psychology, 40, 1-19.

Prado, M. (2011): "Government policy in the formal and informal sectors," European Economic Review, 55, 1120-1136.

Quintin, E. (2008): "Contract enforcement and the size of the informal economy," Economic Theory, 37, 395-416.

Restuccia, D. And R. Rogerson (2008): "Policy Distortions and Aggregate Productivity with Heterogeneous Establishments," Review of Economic Dynamics, 707-720.

Sandmo, A. (2005): "The Theory of Tax Evasion: A Retrospective View," National Tax Journal, 58, 643-63.

SARACOĞLU, D. Ş. (2008): "The informal sector and tax on employment: A dynamic general equilibrium investigation," Journal of Economic Dynamics and Control, 32, 529-549.

Schneider, F. And D. Enste (2000): "Shadow Economies: Size, Cause and Consequences," Journal of Economic Literature, 38, 77-114.

Slemrod, J. (1992): Tax compliance and enforcement. In: Slemrod, J. (Ed.), Why People Pay Taxes, Michigan: University of Michigan Press.

Stiglitz, J. E. (1969): "Distribution of income and wealth among individuals," Econometrica: Journal of the Econometric Society, 382-397.

Torgler, B. AND F. Schneider (2009): "The impact of tax morale and institutional quality on the shadow economy," Journal of Economic Psychology, 30, 228-245.

Trabandt, M. And H. Uhlig (2011): "The Laffer curve revisited," Journal of Monetary Economics, 58, 305-327. 
Traxler, C. (2010): "Social Norms and Conditional Cooperative Taxpayers," European Journal of Political Economy, 89-103.

UlysseA, G. (2018): "Firms, informality, and development: Theory and evidence from Brazil," American Economic Review, 108, 2015-47.

VARVARIGOS, D. (2017): "Cultural norms, the persistence of tax evasion, and economic growth," Economic Theory, 63, 961-995. 


\section{Appendix}

Table VIII: Policy Combination $\left(\zeta, \tau_{w}, \tau_{F}, \lambda_{F}\right)$

\begin{tabular}{|c|c|c|c|c|c|}
\hline & $\begin{array}{l}\zeta^{*}=1.000 \\
\tau_{w}^{*}=0.176 \\
\tau_{F}^{*}=0.317 \\
\lambda_{F}^{*}=2.130\end{array}$ & $\begin{aligned} \zeta^{*} & =1.000 \\
\tau_{w}^{*} & =0.176 \\
\tau_{F} & =0.307 \\
\lambda_{F} & =2.500\end{aligned}$ & $\begin{aligned} \zeta & =1.100 \\
\tau_{w}^{*} & =0.176 \\
\tau_{F}^{*} & =0.317 \\
\lambda_{F} & =2.500\end{aligned}$ & $\begin{array}{c}\zeta^{*}=1.000 \\
\tau_{w}=0.160 \\
\tau_{F}=0.307 \\
\lambda_{F}=2.80\end{array}$ & $\begin{aligned} \zeta^{*} & =1.000 \\
\tau_{w} & =0.140 \\
\tau_{F} & =0.307 \\
\lambda_{F} & =3.000\end{aligned}$ \\
\hline \multicolumn{6}{|l|}{ Formal Sector } \\
\hline Production $\left(y_{F}\right)$ & 64.24 & 74.33 & 80.69 & 82.93 & 85.85 \\
\hline Capital $\left(k_{F}\right)$ & 72.51 & 80.38 & 85.49 & 86.83 & 89.07 \\
\hline Labor $\left(l_{F}\right)$ & 70.96 & 79.57 & 85.23 & 86.81 & 89.22 \\
\hline Entrepreneurs ${ }^{1}$ & 6.2 & 7.42 & 8.07 & 8.16 & 8.35 \\
\hline \multicolumn{6}{|l|}{ Informal Sector } \\
\hline Production $\left(y_{I}\right)$ & 35.68 & 25.67 & 19.31 & 17.07 & 14.15 \\
\hline Capital $\left(k_{I}\right)$ & 27.49 & 19.62 & 14.51 & 13.17 & 10.93 \\
\hline Labor $\left(l_{I}\right)$ & 29.04 & 20.43 & 14.77 & 13.19 & 10.78 \\
\hline Entrepreneurs ${ }^{1}$ & 8.1 & 6.27 & 4.96 & 4.51 & 3.78 \\
\hline \multicolumn{6}{|l|}{$\%$ Variation $(\triangle)^{2}$} \\
\hline$\triangle$ Output $\left(y_{F}+y_{I}\right)$ & 0.0 & 3.73 & 4.54 & 8.15 & 10.21 \\
\hline$\triangle y_{F}$ & 0.0 & 19.87 & 31.13 & 39.43 & 47.10 \\
\hline$\triangle y_{I}$ & 0.0 & -25.37 & -43.41 & -48.26 & -56.31 \\
\hline$\triangle$ Consumption & 0.0 & 1.5 & -0.69 & -0.89 & 0.63 \\
\hline$\triangle$ Tax Revenue & 0.0 & 11.28 & 20.58 & 20.74 & 21.38 \\
\hline$\triangle$ Wage income $^{3}$ & 0.0 & 2.09 & 0.53 & 3.17 & 3.38 \\
\hline
\end{tabular}

Notes: *Baseline values: $\tau_{w}=0.176, \tau_{F}=0.317, \zeta=1, \lambda_{F}=2.13$; (1) Share of entrepreneurs in the sector. Share of workers is one minus the sum of the shares of entrepreneurs in the formal and informal sectors; (2) \% variation relative to the benchmark case; (3) Gross wage income. 